\title{
Relationship Between Performance of the FUNDEB Municipal Board and Active and Passive Waste
}

\author{
Nálbia de Araujo Santos ${ }^{1, \dagger}$ \\ ${ }^{1}$ Universidade Federal de Viçosa, Viçosa, MG, Brazil \\ Luana Aparecida Pereira ${ }^{2, \Omega}$ \\ ${ }^{2}$ Universidade Federal de Viçosa, Viçosa, MG, Brazil \\ Daniele Silva Rodrigues ${ }^{3, ¥}$ \\ ${ }^{3}$ Universidade Federal de Viçosa, Viçosa, MG, Brazil
}

\section{ABSTRACT}

This research verifies the relationship between the lack of action of the FUNDEB Monitoring and Social Control Councils with the indicators of active waste (corruption) and liabilities (mismanagement). The main sources of data used were CGU's audit reports and the websites of FNDE, IBGE and UNDP. The sample is composed of 173 municipalities supervised by the auditors of the CGU, drawn in the 38th, 39th and 40th public draws. The methodological strategies used were the content analysis and the regression for count-data, based on the negative binomial model by maximum likelihood. The results indicated a positive and significant relationship between the lack of action of the FUNDEB Monitoring and Social Control Council and the waste of public resources allocated to basic education related to poor management. This result has a general implication in evaluating the effectiveness of the FUNDEB Control Council's audit function, in accordance with its attributions established by the government's policies and norms.

Keywords: Active and Passive Waste, Social Control, Comptroller General of the Union.

\section{INTRODUCTION}

In order to ensure the execution of policies that aim for a quality basic education and that is accessible to the Brazilian population, the federal government created the Fund for Maintenance and Development of Basic Education and Valorization of Education Professionals (FUNDEB). Their rules are made by the Law $n^{\circ}$ 11494/2007 and by the decree $n^{\circ} 6253 / 2007$. This fund replaced the Fund for Maintenance and Development of the Fundamental Education and Valorization of Teaching (FUNDEF), and started to cover early childhood education, in addition to primary and secondary education.

The financial resources of FUNDEB derive from taxes and transfers from the States, Federal District and Municipalities, in accordance with the provisions of article 212 of the Federal Constitution. In addition to that, the Union is committed to complementing the fund whenever the value per student of each State does not reach the minimum defined nationally. The resources are distributed to all federal entities for use exclusively in the development of basic education in the country. According to data from the National Fund for the Development of
Corresponding author:

+ Universidade Federal de Viçosa,

Viçosa, MG, Brazil

E-mail:nalbia@ufv.br

s Universidade Federal de Viçosa,

Viçosa, MG, Brazil

E-mail: luana_aparecida_pereira@hotmail.com

* Universidade Federal de Viçosa,

Viçosa, MG, Brazil

E-mail: silvar.daniele@gmail.com

Received: 06/25/2017.

Revised: 08/08/2017.

Accepted: $12 / 06 / 2017$.

Published Online: 07/24/2018.

DOI: http://dx.doi.org/10.15728/bbr.2018.15.5.4 
Education (FNDE), it was estimated that in 2017 the resources linked to FUNDEB totaled around 141.4 billion BRL, of which approximately 12.9 billion were complemented by the Union.

However, a recurrent problem is the deviations of public resources by its administrators due to corruption or inefficient management, causing dissatisfaction of the society with the quality of services provided and raising government expenses (LONGO, 2015). This is evidenced in the results of the research by Caldas, Costa and Pagliarussi (2016), which indicate a relation between higher levels of corruption in municipalities with higher levels of expenses in the areas of education and health; however, the increase in total municipal public spending does not mean a positive contribution to society.

In this context, it is worth emphasizing that the findings of FUNDEB's report on the Evaluation of the Execution of Government Programs (AEPG), made by the Comptroller General of the Union (CGU), pointed to: expenses incompatible with the objective of the Fund (58.89\%); assembly, targeting and simulation of bidding processes $(41.12 \%)$; payments in disagreement with legislation (41.93\%); withdrawal at a cash machine $(16.9 \%)$, among other evidences observed in the four states and 120 municipalities inspected in 2013. Moreover, the auditors found evidence that $33.06 \%$ of the Monitoring and Social Control Councils (CACS-FUNDEB) did not follow the execution of the resources, $48.38 \%$ did not supervise the school census execution and $49.19 \%$ of the consultants did not receive training.

This scenario suggests a correlation between the lack of performance of the CACSFUNDEB and the level of resource waste (assets and liabilities) detected by the CGU in the execution of the federal appropriations of the fund. In their studies, Santana (2009) and Vieira (2014) defend this theoretical expectation. Although, the results of the study by Weber (2007) indicated that there was no significant positive correlation between the actions of the municipal councils of Education and Health and the acts of administrative improbity. This divergence of results in the studies with Brazilian data motivated the development of this research.

Amongst recent international research, we find studies that explore social media or social networks as a social control of State actions. In the context of Russia, Enikolopov, Petrova and Sonin (2016), they found that social networks can discipline corruption, even in a country with limited political competition and heavily censored mass media. Based on data from 150 countries, Jha and Sarangi (2017) found a negative relation between the wide use of social media and corruption, and their weight is higher in countries with low freedom of press.

In the face of the contradiction of results observed in the cited studies, the objective of the study is to verify the relation between the lack of performance of the CACS-FUNDEB and the indicators of active (corruption) and passive waste (mismanagement) detected by the CGU in the execution of the federal resources destined for basic education. Thus, we propose to answer the following question: what is the relation between the degree of action of CACS-FUNDEB with the indicators of active and passive waste in the transference of government resources for education? For this purpose, we intend: (1) to identify and classify the irregularities described by the auditors in CGU inspection reports on active or passive waste; (2) identify and classify CACS-FUNDEB characteristics of each municipality as to their effective level of performance; and (3) to evaluate the association between the acting effectiveness indicator of the CACS-FUNDEB and the active and passive waste indexes of the municipalities monitored by CGU.

In order to identify and construct the irregularities profile, described in the CGU inspection reports, as indicators of active and passive waste, we use the variables defined by Ferraz, Finan and Moreira (2008), and later adapted by Dias et al. (2013). We base the degree of the indicator's effectiveness of CACS-FUNDEB's action on the variables outlined by Weber 
(2007), Santana (2009) and Vieira (2014), being identified in the registration data of the boards in the FNDE and the CGU reports. In order to evaluate the relation between the lack of performance of the CACS-FUNDEB and the indicators of active and passive waste, we estimate an econometric Negative Binomial regression model.

The achieved results indicate a positive and significant relation between the ineffectiveness of the FUNDEB Board's actions and the waste of public resources allocated to basic education related to mismanagement. This work contributes to the evaluation of the effectiveness of Social Control in reducing acts of corruption and mismanagement of FUNDEB's government resources, considering the institutional model adopted by the monitored municipalities. This study found that there are failures in the performance in $61.3 \%$ of FUNDEB Councils, especially for not fulfilling their function of supervising the execution of public resources.

The next section presents a review of previous studies regarding inefficiency in the application of public resources, which uses indicators of corruption and mismanagement to obtain their results, and of works focused on evaluating the degree of action of the councils in the task of supervising the implementation of public policies. The third section covers the methodological procedures for carrying out the study and meeting the proposed objectives. The fourth topic describes the results obtained, and the last section summarizes the main conclusions of the study.

\section{PREVIOUS STUDIES}

\subsection{Active and Passive Waste}

Within the international literature, Bandiera, Prat and Valletti (2009) are cited as examples of studies that explored the indicators of corruption and mismanagement to analyze inefficiency in the application of public resources. The authors developed a theoretical framework to examine whether active and passive waste determines the costs of services provided by Italian public agencies. The authors defined active waste as the deviations of resources that directly or indirectly benefited the decision maker (public administrators), as is the case of corruption. Passive waste occurs when employees are poorly prepared or without incentives to properly manage resources without any economic agent being benefited. The result of the study reveals that $83 \%$ of the total irregularities happened due to passive waste (inefficiency of the public management) in the area of purchase of goods carried out by public agencies.

With a focus on analyzing the effect of corruption on countries' public debt, Benfratello, Del Monte and Pennacchio (2017) used panel data from 1995 to 2015. Estimates revealed that corruption increases public debt. However, this effect tends to be heterogeneous in income-related sample divisions, being stronger for the advanced economies and weaker for less developed countries, where external factors such as external assistance can also affect public debt.

In the Brazilian context, for example, we find research by Ferraz, Finan and Moreira (2008), Motta (2010), Dias et al. (2013), Dias (2016) and Caldas, Costa and Pagliarussi (2016) on the subject. Ferraz, Finan and Moreira (2008) constructed indicators of corruption and mismanagement using CGU audit reports, which come from the supervision program based on public draw, to explain the performance of students in Brazil's examinations in the areas of Portuguese and mathematics, conducted in 2005. The results show that corruption significantly reduces students' performance, overriding the effects of other performance determinants, and affects the school indicators, reducing the approval rate and increasing the school dropout one. 
Motta (2010) analyzed the contribution of public purchasing systems, within the scope of the Direct Administration of the Brazilian Federal Executive Power, in improving the efficiency of public expenditure. For the author, the Brazilian purchasing system does not contribute in an essential way to improve the efficiency of public expenditure.

Dias et al. (2013) evaluated which factors of active (corruption) and passive waste (inefficiency) are associated with irregularities in the management of municipal public resources, which the Union transferred to the public health area. The authors analyze the content of the CGU audit reports of 2010. Evidence indicates the existence of the urge to implement governance mechanisms in the public sector, which can reduce active and passive waste.

In another paper by Dias (2016), the focus is to analyze the relation between factors that impact on corruption and inefficiency with the application of municipal public health resources. The results emphasize that the chances of occurrence of corruption and inefficiency in the application of government spending decrease when the attribution of supervision is exercised in an active manner by the Municipal Health Councils (CMS), considered a factor of public governance.

Caldas, Costa and Pagliarussi (2016) reviewed the relation between corruption and government spending composition in Brazilian municipalities. The authors concluded that corruption is positively associated with spending on education and health. According to them, this phenomenon is due in particular to "the discretionary power of municipal expenditures and the legislation in effect in the country, which require minimum expenditures on education and health as a percentage of municipal revenues".

It is noteworthy that the studies cited tend to focus on the phenomenon of corruption and inefficiency. Their results particularly highlight the relation of corruption and inefficiency with increased public expenses.

\subsection{Social CONTRols as an InSTRUMENT FOR REDUCING ACTIVE AND Passive Waste}

For Silva, Cançado and Santos (2017), social control incorporate the process of controlling the actions of the State through social management and through deliberative spaces. From the point of view of the authors, social control encompasses all channels and actions undertaken by society to exercise the control of the State actions. In this way, citizen control actions with the objective of monitoring the execution of the acts of its public administrators, regarding the execution of government expenditures, can collaborate in the fight against corruption and mismanagement. In this context, social control is an instrument that can combat active and passive waste.

According to the CGU Transparency Portal (2014), social control can be carried out either by individuals, i.e., by any citizen, or by organized groups. In addition, public policy management boards are an effective way of organizing social control, and so it can be allowed that citizenship can be effectively exercised. For CGU (2014), "the importance of the councils lies in their role of strengthening the democratic participation of the population in the formulation and implementation of public policies".

Amongst recent international research, we find studies that explore social media or social networks as a social control of the State actions. In the context of Russia, Enikolopov, Petrova and Sonin (2016) found that social networks can discipline corruption, even in a country with limited political competition and heavily censored mass media. Based on data from 150 countries, Jha and Sarangi (2017) found a negative relation between the widespread use of social media and corruption, and their weight is higher in countries with low freedom of press. 
BBR
Among the main responsibilities of the public policy management councils are the activities of monitoring and inspection of the application of public resources. In this respect, Mendes (2004), Weber (2007), Santana (2009), Rausch and Soares (2010), Avelino, Barberia and Biderman (2013) and Vieira (2014) are examples of studies carried out to verify if the councils in the fight against corruption and mismanagement effectively exercise these activities.

Mendes (2004) analyzed the profile of the irregularities pointed out in the reports of CGU, of 67 municipalities, in the municipal management of the federal funds of the Fund for Maintenance and Development of the Fundamental Education and Valorization of Teaching (FUNDEF). The author concluded that the irregularities and diversions of FUNDEF resources were significant. In addition, the author found evidence that monitoring and social control councils present difficulties in carrying out adequate supervision of the execution of public resources. The author suggests that the observed deviations could be reduced if the board's action was more effective.

Weber (2007) pursued to identify the relation between the activities of the councils of social control in the area of health and education and the practice of corruption and administrative probity of municipal managers. The sample comprises of 216 municipalities audited by the CGU via the Inspection Program. The main result of the study pointed out that the board's performance failed to inhibit cases of corruption and mismanagement.

Santana (2009) investigated the effectiveness of local education and health councils as a form of social control and control of public resources. The sample of the study is composed of the municipalities drawn and supervised by the CGU in the 20th to the 23rd public draw. The findings indicated that municipalities with a supervising education council and with broad popular participation registered fewer cases of inefficiency in resource management. In addition, the author concluded that only half of the monitoring and social control councils of the sample have a controlling character.

Rausch and Soares (2010) evaluated how Public Accounts Transparency (TCP) can inhibit the practice of corruption in public management through social control. The authors presented reflections on the need for society to exercise its citizenship, which would lead to pressure on public managers to fulfill the legality and carry out a responsible administration.

Avelino, Barberia and Biderman (2013) aimed to understand the relation between health governance institutions and the incidence of corruption in the local level. The results indicate that the experience of municipal health councils correlates with reductions in the incidence of corruption in public health programs. This impact is significant over time, with each additional year of health care experience reducing the incidence of corruption by $2.1 \%$ in relation to the original values.

Vieira (2014) investigated which would be the causes of corruption through the analysis of the effects of social control, carried out by the municipal councils of public policies. The sample comprised of 960 municipalities, and the results showed that the effective functioning of the municipal councils of education, health and social assistance is associated to the low occurrence of improbities. For Vieira (2014), the municipal councils are the most responsible for the social control of the main public policies of the municipalities.

Accordingly, based on the literature mentioned above, this study investigates the following general hypothesis:

H_general: The lack of action by the municipal Council for Social Monitoring and Control is positively associated with the occurrence of active (corruption) and passive waste (mismanagement) in education expenditures in Brazilian municipalities. 


\section{METHODOLOGICAL PROCEDURES}

\subsection{Description OF THE DATA SOURCE}

The survey data base is the content of 173 Audit Reports of the CGU Auditors of different municipalities, originating from the 38th, 39th and 40th editions of the Supervision Program based on Public Draw, with the supervision being carried out in 2013, 2014 and 2015, and the amounts audited by auditors were approximately 543 million BRL, 274 million and 1.4 billion BRL, respectively. This system of public draws is the same as the lotteries of Caixa Econômica Federal, and is for the selection, in a random and exempt way, of which municipalities will be audited CGU's auditors regarding the execution of federal public funds. Sixty municipalities with a population of up to 500 thousand inhabitants are drawn for each edition. We describe the details of the sample regarding the regional location and size of the municipalities studied in Table 1:

Table 1. Location and size of the audited municipalities.

\begin{tabular}{lcc}
\hline Total of municipalities & 173 & $100 \%$ \\
\hline Location & 20 & $11.6 \%$ \\
Central-West & 16 & $9.2 \%$ \\
North & 71 & $41 \%$ \\
Northeast & 41 & $23.7 \%$ \\
Southeast & 25 & $14.5 \%$ \\
South & & \\
\hline Size & 126 & $72.8 \%$ \\
\hline Small (Up to 20,000 inhabitants) & 37 & $21.4 \%$ \\
Medium (20,001 to 50,000 inhabitants) & 10 & $5.8 \%$ \\
Large (more than de 50,000 inhabitants) &
\end{tabular}

Source: CGU inspection reports for the 38th, 39th and 40th draws.

We reduced the initial sample from 180 to 173 municipalities because CGU auditors in seven municipalities did not supervise the area of education. The municipalities located in the Northeast region represent $41 \%$ of the sample, and $72.8 \%$ of the municipalities audited are of a small size with up to 20,000 inhabitants.

We collected the information on the profile and on the lack of action by CACS-FUNDEB in CGU's inspection reports. In addition to the CGU reports, we also used the data available on the FNDE website, specifically on the FUNDEB Follow-up and Social Control Council home page.

Other sources of data we use are the Brazilian Demographic Census, released by the Brazilian Institute of Geography and Statistics (IBGE) and the United Nations Development Program (UNDP) of 2010. These sources of data served to add relevant information on the socioeconomic profile of the municipalities of the sample.

\subsection{Procedures for Measurement of the Active and Passive Waste Indicators and the Council's Performance}

We use the content analysis technique to interpret the irregularities described in the audit reports of the CGU by its auditors. The main method of analysis we use is the categorical. According to Bardin (1977, p.27), "content analysis is a set of communication analysis techniques", while the categorical analysis method consists of a classification process. 
In order to apply the categorization method, we considered the variables of the studies by Ferraz, Finan and Moreira (2008) as a base, adapted in categories of waste by Dias et al. (2013). In Ferraz, Finan and Moreira (2008) 20 different types of irregularities were identified, which were grouped into two categories denominated corruption and mismanagement. After adapting the variables created by Ferraz et al. (2008), Dias et al. (2013) classified these categories into two indicators: Active and Passive waste.

Dias et al. (2013) identified as active waste when "the private entity obtains financial advantage to the detriment of the financial damage caused to the public entity", also being denominated as corruption. Passive waste occurs "when the public treasury is damaged; however, there is no financial benefit of the private entity in counterpart", and it is considered as inefficiency or mismanagement.

The variables we use in the study to identify and classify the irregularities and construct the indicators of active or passive waste are described in Table 2. To measure these variables, we count the amount of occurrences of each irregularity identified in the report within the appropriate categories.

With these procedures, the variable that designates the occurrence of active waste in the Brazilian municipalities is the result of the sum of the categories "Overbilling", "Bidding with diversion of resources", "Forged bidding" and "Diversion of resources". In addition, the sum of the other categories refers to the passive waste variable. Thus, we present these indicators in quantitative form, but with discrete and non-negative values. Table 3 presents the descriptive statistics of the findings recorded in the database. We do not present the irregularities that we do not observe in the reports in Table 3.

The rate of the active and waste indicator is 3.91, the values of the standard deviation, the minimum and maximum values show a tendency to have dispersion (5.10, 0 and 29). The mean of the findings of the waste indicator is 8.66, the value of the standard deviation (8.16) indicates a considerable dispersion in relation to the rate.

In order to construct the lack of performance index of the FUNDEB Monitoring and Social Control Council, in the studies by Vieira (2014), Santana (2009) and Mendes (2004) describe the variables. In addition, we pursued identifying CGU inspection reports on the performance and structure of the Boards, which were indicated by their auditors during their on-site visits, in terms of their duties as defined by the legislation ${ }^{i}$. Onto measure these variables, described in Table 4, the frequency of evidence was counted, indicating the presence or not of irregularities in CACS-FUNDEB. Thus, it will be possible to construct an ineffective index of performance of each FUNDEB Board per municipality.

The CACS-FUNDEB lack of performance index is a result of the sum of the variables in Table 4. We chose to construct a dummy variable that would indicate if CACS-FUNDEB failed to comply with one of its main duties, which is the one of inspection of government spending. We report the descriptive statistics of these variables in Table 5.

We observed that the mean of the lack of performance index of the CACS-FUNDEB is 1.57 and the maximum value was 7 findings obtained in the municipality. However, it is noteworthy that the auditors found it in $61.3 \%$ of the municipalities audited, CACSFUNDEB contains flaws in its inspection of the execution of public funds by its managers.

Socioeconomic indicators of research developed by IBGE and UNDP, described in Table 6, which were in 2010, were collected to trace the profile of each municipality. Those indicators were chosen because, according to the results of the study by Caldas, Costa and Pagliarussi (2016), they are significantly related to the occurrence of deviation of resources.

${ }^{i}$ Art. 24 of Law $n^{\circ} 11,494 / 2007$; art. $5^{\circ}$ of Law $n^{\circ} 12,487 / 2011$, art. $7^{\circ}$ of Law $n^{\circ}$ 12,499/11; art. 10 of Law $\mathrm{n}^{\mathrm{o}} 12,695 / 2012$. 
Table 2. Variables categorized in Active and Passive Waste.

\begin{tabular}{|c|c|}
\hline Irregularities & Description \\
\hline \multicolumn{2}{|l|}{ Active Waste } \\
\hline Overbilling & $\begin{array}{l}\text { It is the frequency count of evidence of prices paid above market prices, } \\
\text { or when the quantity purchased far exceeds the needs of the municipality. } \\
\text { Numerical scale. }\end{array}$ \\
\hline Diversion of resources & $\begin{array}{l}\text { It is the frequency of cases in which, there are expenses without proof of the } \\
\text { physical part or service rendered. Numerical scale. }\end{array}$ \\
\hline Forged bidding & $\begin{array}{l}\text { It is the frequency of evidence of traces of bidding simulation (assembly), } \\
\text { benefiting some third party. Numerical scale. }\end{array}$ \\
\hline \multicolumn{2}{|l|}{ Passive Waste } \\
\hline Non tax payment & $\begin{array}{l}\text { It is the frequency of cases when the city hall stops paying some tribute. } \\
\text { Numerical scale. }\end{array}$ \\
\hline $\begin{array}{l}\text { Non implementation of } \\
\text { the resource }\end{array}$ & $\begin{array}{l}\text { It is the frequency of cases when the Union gives the money, but the } \\
\text { municipality does not use it. Numerical scale. }\end{array}$ \\
\hline $\begin{array}{l}\text { Unfinished or obsolete } \\
\text { work }\end{array}$ & $\begin{array}{l}\text { It is the frequency of evidence that the mayor leaves unfinished or delayed } \\
\text { work. Numerical scale. }\end{array}$ \\
\hline White elephant & $\begin{array}{l}\text { It is the frequency of cases in which there is a construction or procurement } \\
\text { of goods that is disproportionate to the needs of the municipality. Numerical } \\
\text { scale. }\end{array}$ \\
\hline Irregular bidding & $\begin{array}{l}\text { It is the frequency of cases where there is an irregularity in the bidding } \\
\text { documents (or acquisition of goods without the right bidding). Numerical } \\
\text { scale. }\end{array}$ \\
\hline Fractionation bidding & $\begin{array}{l}\text { It is the frequency of evidence in which the mayor has fractionated the } \\
\text { expenses being carried out in different biddings, aiming to change the type } \\
\text { of bid required, according to regulation established by law. Numerical scale. }\end{array}$ \\
\hline $\begin{array}{l}\text { Bidding with lack of } \\
\text { competition }\end{array}$ & $\begin{array}{l}\text { It is the frequency of cases in which, the bidding does not present a minimum } \\
\text { of three competitors. Numerical scale. }\end{array}$ \\
\hline $\begin{array}{l}\text { Diversion of purpose for } \\
\text { the same sector }\end{array}$ & $\begin{array}{l}\text { It is the frequency of evidence in which, the resource is used for the } \\
\text { maintenance of basic education, but for an objective different from that } \\
\text { initially agreed with the resources of FUNDEB. Numerical scale. }\end{array}$ \\
\hline $\begin{array}{l}\text { Diversion of purpose to } \\
\text { another sector }\end{array}$ & $\begin{array}{l}\text { It is the frequency of cases in which, the resource is used in expenses not } \\
\text { related to basic education. Numerical scale. }\end{array}$ \\
\hline No counterpart & $\begin{array}{l}\text { It is the frequency of cases in which, the municipality does not provide the } \\
\text { counterpart of its responsibility. Numerical scale. }\end{array}$ \\
\hline $\begin{array}{l}\text { Irregular work, product or } \\
\text { service }\end{array}$ & $\begin{array}{l}\text { It is the frequency of evidence in which, the service provided, the product } \\
\text { delivered or the work performed were provided or delivered with the } \\
\text { existence of some minor irregularities. Numerical scale. }\end{array}$ \\
\hline $\begin{array}{l}\text { Irregularity not related to } \\
\text { executor agent }\end{array}$ & $\begin{array}{l}\text { It is the frequency of cases where there are irregularities that are not under } \\
\text { the responsibility of the executing agent. Numerical scale. }\end{array}$ \\
\hline Mismanagement & $\begin{array}{l}\text { It is the frequency of any other irregularity pointed out by the CGU that does } \\
\text { not fit the criteria above. Numerical scale. }\end{array}$ \\
\hline Lack of control & $\begin{array}{l}\text { It is the frequency of cases where there is a lack of adequate control and/or } \\
\text { supervision of assets or programs related to basic education, with signs of } \\
\text { losses. Numerical scale. }\end{array}$ \\
\hline Overweight & $\begin{array}{l}\text { It is the frequency of cases in which contracted prices are above the market } \\
\text { price, but there was no settlement of the expense. Numerical scale. }\end{array}$ \\
\hline $\begin{array}{l}\text { Inadequate condition of } \\
\text { teachers' remuneration }\end{array}$ & $\begin{array}{l}\text { It is the frequency of cases in which, there is evidence of irregularities in the } \\
\text { remuneration of the teaching profession. Numerical scale. }\end{array}$ \\
\hline
\end{tabular}


Table 3. Descriptive statistics of irregularities classified as Active and Passive waste.

\begin{tabular}{lccccc}
\hline Irregularity & Sample & Mean & Standard Deviation & Minimum & Maximum \\
\hline Active Waste & 173 & 3.91 & 5.10 & 0 & 29 \\
\hline Overbilling & 173 & 0.63 & 1.46 & 0 & 13 \\
Diversion of resources & 173 & 1.63 & 2.34 & 0 & 13 \\
Forged bidding & 173 & 1.65 & 2.62 & 0 & 33 \\
\hline Passive Waste & 173 & 8.66 & 8.16 & 0 & 54 \\
\hline Non tax payment & 173 & 0.24 & 0.81 & 0 & 7 \\
Non implementation of the resource & 173 & 0.15 & 0.42 & 0 & 3 \\
Unfinished or obsolete work & 173 & 0.47 & 0.98 & 0 & 7 \\
White elephant & 173 & 0.01 & 0.11 & 0 & 1 \\
Irregular bidding & 173 & 1.47 & 2.15 & 0 & 14 \\
Fractionation bidding & 173 & 0.09 & 0.39 & 0 & 3 \\
Bidding with lack of competition & 173 & 0.01 & 0.08 & 0 & 1 \\
Diversion of purpose to the same sector & 173 & 0.24 & 0.66 & 0 & 4 \\
Diversion of purpose to another sector & 173 & 0.72 & 1.15 & 0 & 6 \\
Non counterpart & 173 & 0.05 & 0.22 & 0 & 1 \\
Irregular work, product or service & 173 & 0.38 & 0.77 & 0 & 4 \\
Irregularity not related to executor agent & 173 & 0.24 & 0.58 & 0 & 3 \\
Mismanagement & 173 & 2.92 & 2.87 & 0 & 19 \\
Lack of control & 173 & 1.36 & 1.52 & 0 & 8 \\
Overweight & 173 & 0.08 & 0.42 & 0 & 4 \\
Inadequate condition of teachers' & 173 & 0.24 & 0.59 & 0 & 3 \\
remuneration & & & & & 3 \\
Source: Elaborated by the authors from & $1 h e$ & CGU & & 0 & 3 \\
& & & & 0 & 0 \\
\end{tabular}

Source: Elaborated by the authors from the CGU inspection reports of the 38th, 39th and 40th drawings.

Table 4. Variables of the Performance Characteristics of the FUNDEB Board.

\begin{tabular}{|c|c|}
\hline Variable & Description \\
\hline $\begin{array}{l}\text { Irregular constitution of the } \\
\text { council }\end{array}$ & $\begin{array}{l}\text { It is the frequency of cases of irregularities in the selection of board } \\
\text { members, and in their register on the FNDE website. Numerical scale. }\end{array}$ \\
\hline Lack of training of members & $\begin{array}{l}\text { It is the frequency of cases in which the members have not received } \\
\text { training to practice the council's duties. Numerical scale. }\end{array}$ \\
\hline Non-supervisory & $\begin{array}{l}\text { It is the frequency of cases in which, the board does not supervise the } \\
\text { application of resources, works, teacher payrolls and does not issue } \\
\text { opinions. Numerical scale. }\end{array}$ \\
\hline $\begin{array}{l}\text { Lack of municipal action to } \\
\text { supply council }\end{array}$ & $\begin{array}{l}\text { It is the frequency of cases in which, the municipality does not provide } \\
\text { the board with necessary inspection documents or other supports such as } \\
\text { suitable meeting place. Numerical scale. }\end{array}$ \\
\hline
\end{tabular}

Source: Elaborated according to the studies by Vieira (2014), Weber (2007), Mendes (2004) and Santana (2009).

We present the descriptive statistics of the variables in Table 6 in Table 7.

The minimum and maximum values of the socioeconomic indicators show discrepancies between the municipalities of the sample. However, the values of the standard deviation of these indicators show that dispersion around the mean is not high. We can consider the values of the means of the municipal educational human development rates and the income 
Table 5. Descriptive Statistics of the Performance Characteristics and the CACS-FUNDEB Performance Index.

\begin{tabular}{lccccc}
\hline Variables & Sample & Mean & Standard Deviation & Minimum & Maximum \\
\hline Irregular constitution of the council & 173 & 0.17 & 0.45 & 0 & 2 \\
Lack of training of members & 173 & 0.27 & 0.48 & 0 & 3 \\
Non-supervisory & 173 & 0.90 & 0.94 & 0 & 6 \\
Lack of municipal action to supply council & 173 & 0.23 & 0.51 & 0 & 2 \\
Lack of action of the Council index & 173 & 1.57 & 1.66 & 0 & 7 \\
Dummy indicating not-acting Council & 173 & 0.61 & 0.49 & 0 & 1 \\
\hline
\end{tabular}

Source: Prepared by the authors from the CGU inspection reports of the 38th, 39th and 40th drawings.

Table 6. Socioeconomic Indicators.

\begin{tabular}{ll}
\hline Indicators & Description \\
\hline $\begin{array}{l}\text { Municipal-Educational Human } \\
\text { Development Index (IDHM-E) }\end{array}$ & $\begin{array}{l}\text { It composes the IDHM-E and is calculated based on the education } \\
\text { situation among the population of the municipality of school age, } \\
\text { besides the schooling of the adult population. }\end{array}$ \\
Per capita income & $\begin{array}{l}\text { Average household income of each individual in the municipality. } \\
\text { GINI index }\end{array}$ \\
It measures the degree of income concentration, ranging from 0 to $1-1$ \\
means complete inequality; and 0, the total equality situation.
\end{tabular}

Source: IBGE and UNDP website, 2010.

Table 7. Descriptive statistics of Socioeconomic Indicators.

\begin{tabular}{lccccc}
\hline Variables & Sample & Mean & Standard Deviation & Minimum & Maximum \\
\hline Municipal-Educational Human & 173 & 0.55 & 0.09 & 0.28 & 0.76 \\
Development Index (IDHM-E) & & 434.28 & 197.76 & 123.16 & 973.81 \\
Per capita income & 173 & 0.50 & 0.06 & 0.33 & 0.8 \\
GINI index & 173 &
\end{tabular}

Source: Elaborated by the authors based on IBGE and UNDP data from 2010.

inequality of the municipalities of the sample intermediate. However, the average per capita income of the municipalities in the sample is less than a minimum wage $\mathrm{e}^{\mathrm{ii}}$.

\subsection{ECONOMETRIC MODELS}

The dependent variables of this study assume only integer and positive values; therefore presenting themselves as a count data structure. Consequently, they are not continuous variables, so they do not have a normal distribution, so the use of ordinary minimums squares regression models is not appropriate. In addition, we assume a fixed time interval, since each observation is a municipality in a given year and is does not repeat every year.

In the face of the design of the database, we choose to use the regression model for count data. In this sense, the Poisson and Negative Binomial regression models are alternative estimates. The Poisson model is appropriate in cases where the dependent variables present average and close variance (Long and Freese, 2001). However, if there is overdispersion (when the obtained variance is higher than the average) in the data, Long and Freese (2001) recommend the use of the Binomial Negative model.

\footnotetext{
ii The minimum wage in 2010, the year of the CENSO, was R\$510.00.
} 
BBR

Initially, we analyze the mean and variance values of the Active (3.91 and 26.0) and Passive wastes (8.7 and 66.6), and based on the Goodness-of-Fit test, we verified the presence of overdispersion. The presence of overdispersion in the data points to the nonadequacy of the Poisson model, so the regression model adopted is the negative binomial (Long and Freese, 2001).

Four models are estimated to capture the relation between the lack of performance of the CACS-FUNDEB and the indicators of active $(d a)$ and passive waste $(d p)$ in the municipalities of the sample. In the first two models, the dependent variable is the indicator of active wastes. The independent variables of interest will be the index of lack of action of the Council (ind_cons), in the first estimate, and, in the second moment, the dummy indicating that the Council did not inspect ( $d$ _cons) the application of the public resources of a municipality $i$, which was audited in year $t$, in its absolute frequency value. The socioeconomic indicators index of GINI (gini), per capita income (income) and the index of municipal human educational development $\left(i d h m_{-} e\right)$ are the selected control variables.

The other two models, the dependent variable becomes the passive waste indicator in its absolute frequency value. The independent variables are identical to the variables of the other two models. Therefore, we estimate the following models by negative binomial regression by maximum likelihood:

$$
\begin{aligned}
& d a \lambda_{i t}=e^{\left(\alpha+\beta_{1} . i n d_{c o n s} 1 i t+\beta_{2} . g i n i 2 i t+\beta_{3} . i n c o m e 3 i t+\beta_{4} . i d h m_{e} 4 i t+\epsilon_{i t::}\right)} \\
& d a \lambda_{i t}=e^{\left(\alpha+\beta_{1} . d_{\text {cons }} 1 i t+\beta_{2} . \text { gini2it }+\beta_{3} . i n c o m e 3 i t+\beta_{4} . \text { idhm }_{e} 4 i t+\epsilon_{i:: i}\right)} \\
& d p \lambda_{i t}=e^{\left(\alpha+\beta_{1} . \text { ind }_{\text {cons }} 1 i t+\beta_{2} . \text { gini2it }+\beta_{3} . i n c o m e 3 i t+\beta_{4} . i d h m_{e} 4 i t+\epsilon_{i:: s}\right)} \\
& d p \lambda_{i t}=e^{\left(\alpha+\beta_{1} . d_{\text {cons }} 11 t+\beta_{2} . g i n i 2 i t+\beta_{3} . i n c o m e 3 i t+\beta_{4} . i d h m_{e} 4 i t+\epsilon_{i:::}\right)}
\end{aligned}
$$

In each one of the models, the parameter $\beta 1$ is estimated, i.e., to infer which is the relation of the lack of action of the Boards (social control) on the indicators of active and passive waste $\lambda$, which corresponds to the expected number of irregularities classified in the respective rates. We will use the signal and level of significance for the general hypothesis of this study. It should be noted that we performed the statistical procedures of the negative binomial regression technique using Stata software version 14.

\section{RESULTS AND DISCUSSIONS}

\subsection{RESULTS OF THE ANALYSIS OF THE RELATION BETWEEN THE LACK OF ACTION OF THE BOARD WITH THE INDICATORS OF ASSET AND LIABILITY WASTE}

We show the results of the negative binomial models estimated by maximum likelihood in Table 8, reporting the coefficients and the standard error on the line below it. On the first column of Table 8 , the results of the estimations between the Council's lack of performance index (ind_cons) and the active waste indicator, model 1, are shown, controlled by socioeconomic indicators. In the second estimated model, we replace this index by the dummy that the Council did not supervise (d_cons) the application of governmental resources.

In general, the results of models 1 and 2 indicate that the variables ind_cons and $d$ _cons were not significantly associated with the occurrence of active wastes. This result shows that the failures of CACS-FUNDEB performance are not related to the evidences of corruption 
Table 8. Results of the estimates of the negative binomial model on the lack of performance of the Board with the indicators of active and passive waste.

\begin{tabular}{|c|c|c|c|c|}
\hline & Model 1 & Model 2 & Model 3 & Model 4 \\
\hline Dependent variables & Active Waste & Active Waste & Passive Waste & Passive Waste \\
\hline \multicolumn{5}{|l|}{ Independent variables } \\
\hline Constant & $\begin{array}{c}0.70 \\
(0.613)\end{array}$ & $\begin{array}{c}0.48 \\
(0.730)\end{array}$ & $\begin{array}{c}1.47 \\
(0.101)\end{array}$ & $\begin{array}{c}0.89 \\
(0.350)\end{array}$ \\
\hline $\begin{array}{l}\text { Lack of Performance of the } \\
\text { Council Index }\end{array}$ & $\begin{array}{c}0.08 \\
(0.181)\end{array}$ & $\begin{array}{l}- \\
-\end{array}$ & $\begin{array}{c}0.20 * * * \\
(0.000)\end{array}$ & $\begin{array}{l}- \\
-\end{array}$ \\
\hline $\begin{array}{l}\text { Dummy Indicates Lack of } \\
\text { Inspection of the Council }\end{array}$ & $\begin{array}{l}- \\
-\end{array}$ & $\begin{array}{c}0.10 \\
(0.633)\end{array}$ & $\begin{array}{l}- \\
-\end{array}$ & $\begin{array}{l}0.38^{* * *} \\
(0.007)\end{array}$ \\
\hline Gini Index & $\begin{array}{l}4.29 * * \\
(0.033)\end{array}$ & $\begin{array}{l}4.88^{* *} \\
(0.014)\end{array}$ & $\begin{array}{c}1.76 \\
(0.131)\end{array}$ & $\begin{array}{l}3.06^{* *} \\
(0.013)\end{array}$ \\
\hline $\begin{array}{l}\text { Municipal-Educational Human } \\
\text { Development Index (IDHM-E) }\end{array}$ & $\begin{array}{l}-1.22 \\
(0.482)\end{array}$ & $\begin{array}{l}-1.04 \\
(0.551)\end{array}$ & $\begin{array}{l}-0.71 \\
(0.544)\end{array}$ & $\begin{array}{l}-0.11 \\
(0.929)\end{array}$ \\
\hline Per capita income & $\begin{array}{c}-0.003 * * * \\
(0.001)\end{array}$ & $\begin{aligned} &-0.003 * * * \\
&(0.000)\end{aligned}$ & $\begin{array}{l}-0,006 \\
(0.274)\end{array}$ & $\begin{array}{c}-0.001 * * \\
(0.026)\end{array}$ \\
\hline /lnalpha & 0.07 & 0.09 & -0.78 & -0.62 \\
\hline Alpha & 1.08 & 1.10 & 0.46 & 0.53 \\
\hline Prob $>$ chi $^{2}$ alpha & 0.000 & 0.000 & 0.000 & 0.000 \\
\hline Sample & 173 & 173 & 173 & 173 \\
\hline LR chi ${ }^{2}$ & 55.58 & 55.58 & 60.85 & 42.85 \\
\hline Prob $>$ chi $^{2}$ & 0.0000 & 0.0000 & 0.0000 & 0.0000 \\
\hline Pseudo predicted $\mathrm{R}^{2}$ & 0.0661 & 0.0661 & 0.0550 & 0.0387 \\
\hline Log likelihood & -392.87 & -392.87 & -522.84 & -531.84 \\
\hline Prob $>$ chibar $^{2}$ & 0.000 & 0.000 & 0.000 & 0.000 \\
\hline
\end{tabular}

Source: Elaborated based on research data. Note: Value of statistics z in brackets. Significance level at $* 10 \%, * *$ at $5 \%$ and $* * *$ at $1 \%$. Statistics calculated for 173 municipalities of the sample.

found by CGU's auditors. Thereby, the hypothesis initially defended is inconsistent for the active waste variable. This result diverges from the study by Dias (2016), which pointed out that there is a relation between the supervision action of the Municipal Health Councils (CMS) and the incidence of corruption in health spending in Brazilian municipalities. This divergence in the findings deserves an in-depth analysis; since it may be pointing out that the institutional model of the sample Boards and their current legal attributions do not interfere in government actions to reduce acts of corruption.

Among the socioeconomic indicators, Gini and Income per capita were significant. These results allow us to infer that in municipalities with higher income per capita the chances of assets waste occurring are reduced. However, the chances of occurrence of active waste increases when the municipality has high concentration of income.

In model 3 we analyze the relation between the lack of performance index of the Council (ind_cons) and the indicator of passive waste, controlled by socioeconomic indicators. In the fourth estimated model, this indicator is replaced by a dummy that the Council did not supervise ( $d$ _cons) the application of governmental resources. The results of models 3 and 4 , presented in Table 8, indicate that the variables ind_cons and $d$ cons are positively and significantly associated with the findings of passive wastes, which are considered acts of mismanagement. The signs obtained from the coefficients of the variables related to the lack of action of the Councils with passive wastes being consistent with the hypothesis. 
BBR

Therefore, the chances of occurrence of passive waste increase significantly when the municipality has a CACS-FUNDEB with failures in its constitution, performance and when it did not perform its legal attribution to supervise the execution of resources passed through the Union.

This result differs from the findings by Weber (2007) and corroborate with the theoretical expectation by Mendes (2004), Santana (2009), Avelino, Barberia and Biderman (2013) and Vieira (2014) and Dias (2016). The divergence of this result with the findings of Weber (2007) may be due to the scale used to measure the degree of action of the council, which was only the frequency of meetings being collected through the research "Profile of Brazilian Municipalities: Public Management - 2001", published by IBGE. The content analysis procedure allowed providing evidence that there is a disagreement between the data declared on the follow-up sites by councils on the frequency of board meetings with the reality pointed out in the CGU reports, indicating that this measure may contain inconsistency. In addition, the CGU auditors found that the boards did not supervise the application of resources ( $61 \%$ of the sample), although they maintained a certain frequency of meetings. The auditors also found that in some municipalities the meeting tariffs were about exchanges of members and provision of services of the programs without real evidence of follow-ups and inspections of the execution of FUNDEB resources. In light of this evidence, using only frequencies from meetings collected may not be sufficient to evaluate the performance of CACS-FUNDEB. In this context, we suggest as a source of data of possible failures in the fulfillment of the attributions of the Councils the information contained in the reports of inspections of the CGU.

In model 3, the Gini indicator and the per capita income were not significant. The coefficients of the Gini indicator and the per capita income of model 4 are significant, indicating that in municipalities with higher per capita income, the chances of passive waste occur are reduced. However, the chances of occurrence of passive waste increase significantly when the municipality has high a concentration of income.

The estimates of the models as a whole are in the last lines of Table 8 . The results of the Prob $>$ chi 2 statistic indicate that the estimated parameters are statistically different from zero at a significance level of $1 \%$. We describe the values of the Log pseudo-likelihood because of the use of the robust standard error. The Wald chi2 test results from all four models indicate their significance as a whole.

\section{FINAL CONSIDERATIONS}

The results of previous empirical studies diverge on the actions of the municipal councils of Education and Health in reducing or increasing the acts of administrative improbity by the public agents. The objective of this study is to verify the relation between the lack of action of the FUNDEB Monitoring and Social Control Councils with the indicators of active (corruption) and passive waste (mismanagement).

The results of the estimates suggest that passive waste findings tend to be higher in the municipalities of the sample where the CACS-FUNDEB did not carry out the proper inspection of the application of the public resources. In addition, we found evidence that failures in the institutional or governance structure of CACS-FUNDEB in the municipalities of the sample tend to increase the incidence of active waste.

The findings described in the audit reports by CGU's auditors enabled us to consider that there is a lack of a local policy to support the proper functioning of the CACS-FUNDEB in part of the municipalities of the sample. The results provide evidence that legal assignments for example, monitoring and controlling the execution of federal resources transferred to the account of the National Support Program for Transportation of Schoolchildren - PNATE and the Support Program for Education Systems to Assist Youth and Adults Education, as 
determined by art. 24 of Law №. 11,494/2007 —, are not being adequately carried out by the members of CACS-FUNDEB for about $61 \%$ of the municipalities of the sample.

Evidence of the failures of the Council's actions, as pointed out in the reports of CGU's auditors, reinforces the need to rethink and create incentive mechanisms so that its members can effectively monitor the application of public resources. These incentives can improve the perception of its members about their role in social control in the execution of resources, which can bring benefits for basic education to their municipality.

This study contributes highlighting the relevance of the Municipal Councils as an instrument of monitoring and control in the application of public resources. In addition, it describes the main failures that have occurred for this social control not being effective. This study reinforces that society needs to monitor whether the mayors of the municipalities legitimize CAS-FUNDEB's assignments and offer adequate infrastructure for their members to carry out their monitoring and inspection activities effectively, be it in relation to education councils or other areas.

Although, improving the effective performance of Social Control is not the only solution to reduce and prevent waste, whether passive or active. Other solutions deserve further study. For example, studies by Mendes (2004) and Bandiera, Prat and Valletti (2009) suggest the creation of a more efficient public purchasing system to combat all kinds of waste of resources.

Therefore, we suggest that it deserved a more in-depth analysis of the profile of CACSFUNDEB members, as to their degree of exemption for judgment, involvement with the mayor or political party, as was the process of nominating their members, among others points. This profile analysis may suggest that the current governance model of Social Control needs adjustments to attenuate at least the legislation and resize its attributions.

\section{REFERENCES}

AVELINO, George; BARBERIA, Lorena G.; BIDERMAN, Ciro. Governance in managing public health resources in Brazilian municipalities. Health Policy and Planning Advance, 15, p. 1-9, February, 2013. doi: $10.1093 /$ heapol $/$ czt003

BANDIERA, O., Prat, A., \& VALLETTI, T. (2009). Active and passive waste in government spending: evidence from a policy experiment. American Economic Review, 99 (4), 1278-1308.

BARDIN, Laurence. Análise de Conteúdo. Tradução de Luís Antero Reto e Augusto Pinheiro. Lisboa: Edições 70, 1977.

BENFRATELLO, L.; DEL MONTE, A. ; PENNACCHIO, L. (2017). Corruption and public debt: a crosscountry analysis. Journal Applied Economics Letters, p. 1-5, 2017. http://dx.doi.org/10.1080/13504851.2 017.1321831

CALDAS, Olavo Venturim; COSTA, Cristiano Machado; PAGLIARUSSI, Marcelo Sanches. Corrupção e Composição dos Gastos Governamentais: evidências a partir do Programa de Fiscalização por Sorteios Públicos da Controladoria-Geral da União. Revista de Administração Pública, 50(2), pp. 237-264, mar./ abr. 2016.

CONTROLADORIA GERAL DA UNIÃO (CGU). Portal da Transparência do Governo Federal. Controle Social - Conselhos municipais e controle social. Disponível em: <http://www.portaldatransparencia.gov. $\mathrm{br} /$ controlesocial/ConselhosMunicipaiseControleSocial.asp> Acesso em: 2 set. 2015.

CONTROLADORIA GERAL DA UNIÃO (CGU). 38을 $39^{\circ}$ e $40^{\circ}$ Sorteios do Programa de Fiscalização por Sorteios Públicos. Disponível em: < http://www.cgu.gov.br/assuntos/auditoria-e-fiscalizacao/avaliacaode-programas-de-governo/programa-de-fiscalizacao-em-entes-federativos/sorteios-publicos/municipios/ copy_of_38-sorteio >. Acesso em: 2 set. 2015.

CONTROLADORIA-GERAL DA UNIÃO (CGU). Relatórios de Auditoria, Fiscalização e Avaliação № 39: Disponível em: $<\mathrm{http}: / /$ sistemas2.cgu.gov.br/relats/relatorios.php?linha_atuacao $=\mathrm{Avalia} \% \mathrm{C} 3 \% \mathrm{~A} 7 \% \mathrm{C} 3 \%$ $\mathrm{A} 3 \mathrm{o}+\mathrm{da}+\mathrm{Execu} \% \mathrm{C} 3 \% \mathrm{~A} 7 \% \mathrm{C} 3 \% \mathrm{~A} 3 \mathrm{o}+\mathrm{de}+$ Programas $+\mathrm{de}+$ Governo $+\% 2 \mathrm{~F}+$ Relat $\% \mathrm{C} 3 \% \mathrm{~B} 3 \mathrm{rio}+\mathrm{de}+\mathrm{Fiscal}$ iza $\% \mathrm{C} 3 \% \mathrm{~A} 7 \% \mathrm{C} 3 \% \mathrm{~A} 3 \mathrm{o}+\mathrm{em}+\mathrm{Munic} \% \mathrm{C} 3 \% \mathrm{ADpios} \& \mathrm{ano}=\&$ titulo $=\&$ ministerio=Selecione\&ano_exerci $\mathrm{cio}=\&$ programa $=$ Selecione $\& u f=$ Selecione $\&$ municipio $=$ Selecione\&sorteio $=39>$. Acesso em: 2 set. 2015 . 
BBR

15,5
DIAS, L. N. S. et al. Fatores Associados ao Desperdício de Recursos da Saúde Repassados pela União aos Municipios Auditados pela Controladoria Geral da União. Revista de Contabilidade Financeira - USP, São Paulo, 24 (63), p.206-218. 2013.

DIAS, L. N. S. Fatores que impactam na corrupção e na ineficiência relacionadas à aplicação de recursos da saúde pública municipal. 2016. 157 f. Teses (Doutorado em Ciências Contábeis) - Universidade de Brasília, Universidade Federal da Paraíba e Universidade Federal do Rio Grande do Norte, Brasília, 2016.

ENIKOLOPOV, Ruben, PETROVA, Maria and SONIN, Konstantin, (2016), Social Media and Corruption, No 11263, CEPR Discussion Papers, C.E.P.R. Discussion Papers, Disponível em: <https://EconPapers. repec.org/RePEc:cpr:ceprdp:11263>.Acesso em: 08 set. 2017.

FERRAZ, C., FINAN, F., \& MOREIRA, D. B. (2008). Corrupção, má gestão, e desempenho educacional: evidências a partir da fiscalização dos municípios. Anais do XXXVI Encontro Nacional de Economia, Salvador, BA, Brasil. Disponível em: <http://www.anpec.org.br/encontro2008/artigos/200807211421560-. pdf $>$. Acesso em: 4 ago. 2015.

FUNDO NACIONAL DE DESENVOLVIMENTO DA EDUCAÇÃO (FNDE). CACS- Conselho de Acompanhamento e Controle Social do FUNDEB. Disponível em $<$ https://www.fnde.gov.br/cacs/index. php/lista_conselheiros> Acesso em 13 set. 2015.

JHA, Chandan Kumar; SARANGI, Sudipta. Does social media reduce corruption? Information Economics and Policy, 39, pp. 60-71, June 2017. DOI: https://doi.org/10.1016/j.infoecopol.2017.04.001

LONG, J. S; FREESE, J. Regression models for categorical dependent variables using STATA. Texas, Stata Press Publication, 2001.

LONGO, Gustavo Frederico. Avaliação dos impactos das auditorias da CGU nos recursos do FUNDEF. Revista da CGU, Brasília, 2015.

MENDES. Marcos. Análise das Irregularidades na Administração Municipal do FUNDEF: Constatações do Programa de Fiscalização a Partir de Sorteios Públicos da Controladoria-Geral da União. São Paulo: Transparência Brasil, 2004. 31p.

MOTTA, A. R. (2010). O combate ao desperdício no gasto público: uma reflexão baseada na comparação entre os sistemas de compra privado, público federal norte-americano e brasileiro. Dissertação de mestrado, Universidade Estadual de Campinas, Instituto de Economia, Campinas, São Paulo, Brasil.

RAUSCH, R. B.; SOARES, M. Controle social na administração pública: a importância da transparência das contas públicas para inibir a corrupção. Revista de Educação e Pesquisa em Contabilidade, Brasília, v. 4, n. 3, art. 2, p. 23-43, set/dez. 2010.

SANTANA, V. L. Controle social e desempenho da gestão pública: uma análise empírica dos conselhos locais

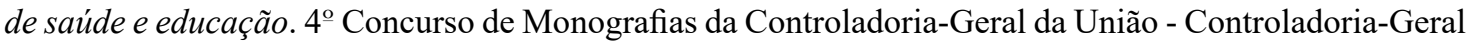
da União, Brasília, DF, 2009. p. 11 - 35.

SILVA, Fernanda Rodrigues da; CANÇADO, Airton Cardoso; SANTOS, Jeany Castro dos. Compreensões Acerca do Conceito de Controle Social. Desenvolvimento em Questão, 15 (41), 2017. DOI: http://dx.doi. org/10.21527/2237-6453.2017.41.24-58

VIEIRA, J. B. Os conselhos de políticas públicas são uma estratégia efetiva de combate à corrupção? Uma análise do controle social das políticas públicas nos municípios brasileiros. In: IX Encontro da ABCP, 2014, Brasília. Anais do IX Encontro da ABCP. Brasília: ABCP, 2014. p. 1-23.

WEBER, Luiz Alberto. Controle social em xeque - o colapso dos conselhos municipais como arenas de discussão da corrupção política. $2^{\underline{0}}$ Concurso de Monografias da Controladoria-Geral da União Controladoria-Geral da União, Brasília, DF, 2007. 50 p. 